\title{
Strontium to calcium ratios in the marine gastropod Conus ermineus: Growth rate effects and temperature calibration
}

\section{Sindia Sosdian}

Institute of Marine and Coastal Sciences, Rutgers University, 71 Dudley Road, New Brunswick, New Jersey 08901, USA (sosdian@imcs.marine.rutgers.edu)

\section{Keith Gentry}

Department of Geology and Geophysics, Texas A\&M University, College Station, Texas 77843, USA

Caroline H. Lear

School of Earth, Ocean, and Planetary Sciences, Cardiff University, Cardiff, CF10 3YE, United Kingdom

Ethan L. Grossman

Department of Geology and Geophysics, Texas A\&M University, College Station, Texas 77843, USA

\section{David Hicks}

Department of Biological Sciences, University of Texas at Brownsville, 80 Fort Brown, Brownsville, Texas 78520, $U S A$

\section{Yair Rosenthal \\ Institute of Marine and Coastal Sciences and Department of Geological Sciences, Rutgers University, New Brunswick, New Jersey 08901, USA}

[1] Here we investigate the potential of $\mathrm{Sr} / \mathrm{Ca}$ ratios in the marine gastropod Conus ermineus for reconstructing seawater temperatures. We present annually resolved records of $\mathrm{Sr} / \mathrm{Ca}$ and $\delta^{18} \mathrm{O}$ for four shells collected alive from the Flower Garden Banks National Marine Sanctuary in the Gulf of Mexico. Our results show that variations in $\mathrm{Sr} / \mathrm{Ca}$ and $\delta^{18} \mathrm{O}$ covary with the in situ seasonal temperature cycle. $\mathrm{Sr} /$ $\mathrm{Ca}$ and temperature are positively correlated, in contrast with the inverse relationship found in inorganically precipitated aragonite. The seasonal $\mathrm{Sr} / \mathrm{Ca}$ variability is superimposed on a long-term trend of increasing $\mathrm{Sr} / \mathrm{Ca}$ with age. Both the seasonal and long-term ontogenetic changes in $\mathrm{Sr} / \mathrm{Ca}$ are associated with variations in growth rate, defined here as the shell linear extension rate (LER); the seasonal variability in LER is superimposed on a long-term decrease with ontogeny. Thus the covariance of $\mathrm{Sr} / \mathrm{Ca}$ ratios with temperature and LER suggests that $\mathrm{Sr}$ incorporation is likely driven by temperature influence on growth rate, rather than by thermodynamic effects. Unlike the seasonal variability, the ontogenetic effect is characterized by inverse covariation between $\mathrm{Sr} / \mathrm{Ca}$ and LER, suggesting that $\mathrm{Sr} / \mathrm{Ca}$ variability is not controlled by growth rate alone, but probably by two different biomineralization mechanisms, one related to temperature and the other related to age. We use the seasonal $\mathrm{Sr} / \mathrm{Ca}$ signal of four shells to construct a temperature calibration. To minimize the ontogenetic effects, we separate the records into juvenile and adult growth stages and calculate the $\mathrm{Sr} / \mathrm{Ca}$-temperature $(\mathrm{T})$ relationships:

Juvenile: $\mathrm{Sr} / \mathrm{Ca}\left(\mathrm{mmol} \mathrm{mol}{ }^{-1}\right)=0.042( \pm 0.008) * \mathrm{~T}\left({ }^{\circ} \mathrm{C}\right)+0.24( \pm 0.21)\left(\mathrm{R}^{2}=0.66\right)$

Adult: $\mathrm{Sr} / \mathrm{Ca}\left(\mathrm{mmol} \mathrm{mol}{ }^{-1}\right)=0.072( \pm 0.014) * \mathrm{~T}\left({ }^{\circ} \mathrm{C}\right)-0.05( \pm 0.34)\left(\mathrm{R}^{2}=0.68\right)$

Applying the calibration to a single specimen provides mean annual temperature estimates within $\pm 1{ }^{\circ} \mathrm{C}$ of the in situ temperature record but resolves the seasonal variability only within $\pm 3.5^{\circ} \mathrm{C}$. The large error in 
the seasonal estimates reflects the high variability among specimens. To reduce the uncertainty on seasonal temperatures, we propose combining records from multiple shells to generate an average temperature record. The potential of this approach needs, however, to be validated in other locations.

Components: 7823 words, 10 figures, 3 tables.

Keywords: temperature; gastropod; $\mathrm{Sr} / \mathrm{Ca}$; Conus ermineus; mollusk; paleothermometer.

Index Terms: 4825 Oceanography: Biological and Chemical: Geochemistry; 4227 Oceanography: General: Diurnal, seasonal, and annual cycles (0438); 4924 Paleoceanography: Geochemical tracers.

Received 26 December 2005; Revised 10 July 2006; Accepted 30 August 2006; Published 30 November 2006.

Sosdian, S., D. K. Gentry, C. H. Lear, E. L. Grossman, D. Hicks, and Y. Rosenthal (2006), Strontium to calcium ratios in the marine gastropod Conus ermineus: Growth rate effects and temperature calibration, Geochem. Geophys. Geosyst., 7, Q11023, doi:10.1029/2005GC001233.

\section{Introduction}

[2] Fundamental to reconstructing past climate is our ability to extract quantitative paleotemperatures from marine sediments. Many of these sediments consist of biogenic calcium carbonate (e.g., foraminifera test, coral skeleton, and mollusk shell), which contains within the lattice trace elements that may record environmental conditions (e.g., $\mathrm{Mg}, \mathrm{Sr}, \mathrm{Ba}, \mathrm{Cd}$, and $\mathrm{U}$ ). Corals and mollusks are particularly useful for isotopic and trace element studies because of their rapid skeleton accretion, which can result in a high-resolution archive of paleoenvironmental variability. Mollusks, especially bivalves, have been rigorously studied for their ability to record past temperatures, salinity, and productivity [e.g., Dodd, 1965; Jones and Quitmeyer, 1996; Elliot et al., 2003; Ivany et al., 2004]. Fewer studies, however, have investigated the isotope and trace metal composition of gastropods and their paleoenvironmental applications [e.g., Buchardt and Fritz, 1978; Rosenthal and Katz, 1989; Purton et al., 1999; Andreasson and Schmitz, 1998; Tripati and Zachos, 2002]. Among the latter are Kobashi et al. [2001], Kobashi and Grossman [2003], and Kobashi et al. [2004], who have examined isotopic records of fossil and modern Conus ermineus shells collected from different sites in the Gulf of Mexico. They note a good correlation between $\delta^{18} \mathrm{O}$ and temperature, which suggests that $\delta^{18} \mathrm{O}$ closely traces seasonal variations in seawater temperature. Using $\delta^{18} \mathrm{O}$ records in fossil Conus shells, Kobashi et al. [2001] detail a record of cooling and increased seasonality in the U.S. Gulf Coast during the Tertiary. Interpretations of $\delta^{18} \mathrm{O}$ in terms of paleotemperature variability might be limited, however, by lack of information about the oxygen isotopic composition of seawater $\left(\delta_{\mathrm{w}}\right)$; variations in seawater $\delta_{\mathrm{w}}$ are caused by both long-term changes in the extent of continental ice sheets and local changes in freshwater input and evaporation. To circumvent this problem, the use of trace metal-temperature relations as a paleothermometer independent of salinity variations (e.g., $\mathrm{Mg} / \mathrm{Ca}$ ratios in foraminifera [Nurnberg et al., 1996; Rosenthal et al., 1997] and coralline $\mathrm{Sr} / \mathrm{Ca}$ [Weber, 1973; Beck et al., 1992]) have been investigated. Such proxies allow us to estimate paleotemperatures, and combined with $\delta^{18} \mathrm{O}$ measurements, to estimate $\delta_{\mathrm{w}}$ and make inferences about continental ice volume and local salinity [e.g., Lear et al., 2000; Lea et al., 2000]. In this study, we examine the effects of temperature and growth rate on the $\mathrm{Sr} / \mathrm{Ca}$ composition of Conus shells to refine their use as repositories of paleoenvironmental information.

[3] Gastropods are widely distributed in the tropical and subtropical oceans. The high deposition rate of their shell along with their longevity (57 years) make them potentially powerful archives of short-term paleoenvironmental variability [Kohn and Perron, 1994]. Conus ermineus, studied here, typically lives in the mixed layer and thus approximately records sea surface temperatures (SST). Its shell consists of aragonite [Kohn et al., 1979], and although aragonite is the less stable polymorph of $\mathrm{CaCO}_{3}$ and may be altered to calcite during diagenesis, aragonite preservation offers a direct and simple way to identify diagenetic alteration in fossil samples.

[4] Mollusk biomineralization occurs at the mantle, a thin organic lining on the inner shell surface. Between the mantle and shell surface is the extrapallial fluid, which is an enclosed environment, isolated from seawater. Unlike corals, which 


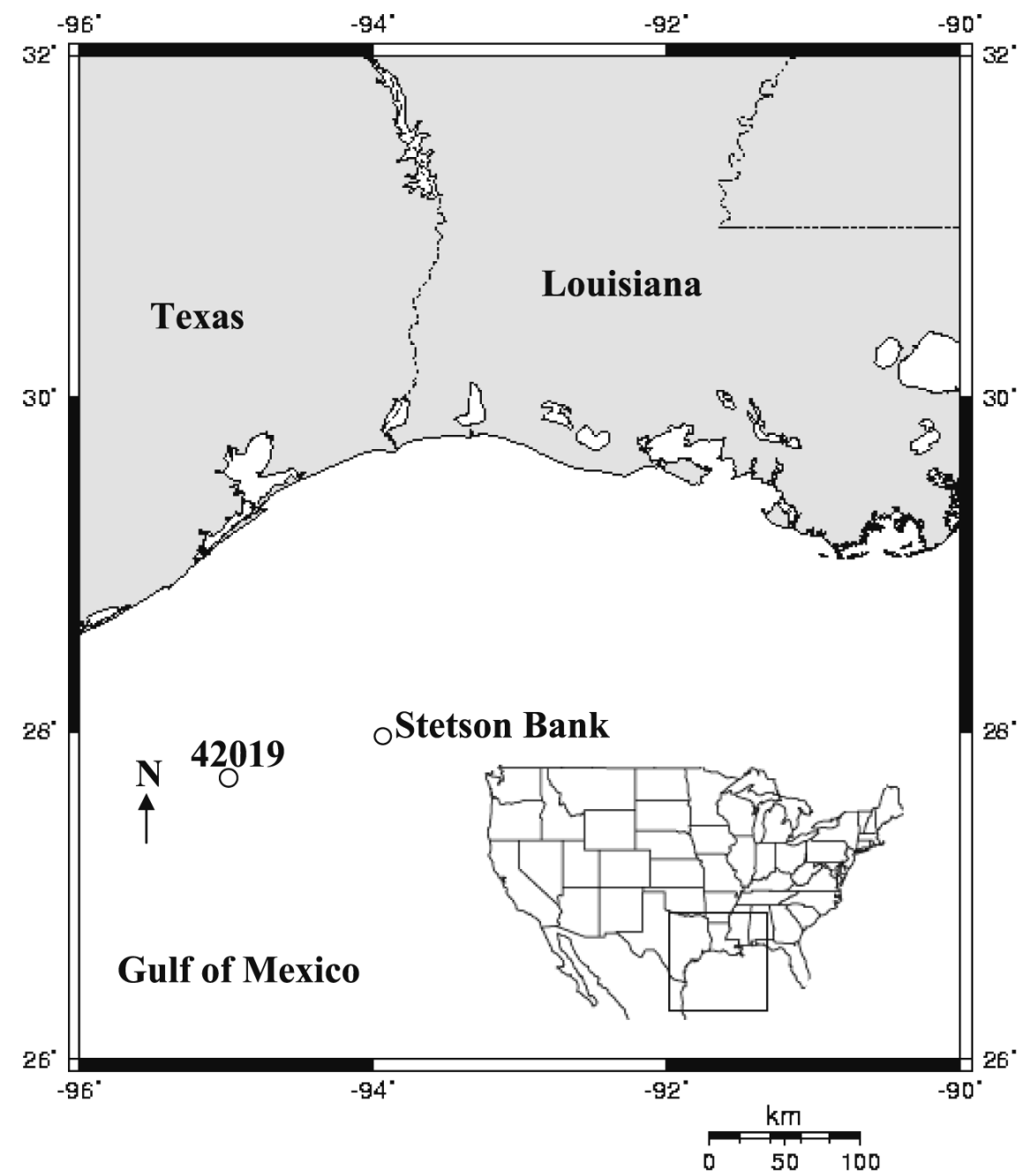

Figure 1. Map of U.S. Gulf Coast showing Flower Garden Banks National Marine Sanctuary, the location where Conus ermineus shells were collected and hydrographic parameters were measured. One hundred kilometers west of Stetson bank, the site of sample collection, is the NDBC \#42019, which is used to extend the temperature record to earlier growth cycles.

crystallize directly from seawater [Cohen and McConnaughey, 2003], both gastropods and bivalves derive their shell substrate from the extrapallial fluid [Wilbur and Salenddin, 1983]. The crystallization process is highly mediated by physiology [Wada and Fujinuki, 1976]. Thus, although thermodynamics play an important role in determining the shell $\mathrm{Sr} / \mathrm{Ca}$, biological effects such as ontogeny, metabolism, and growth rate must also be considered. A few studies have documented an apparent temperature effect on bivalve $\mathrm{Sr} / \mathrm{Ca}$, with increasing $\mathrm{Sr} / \mathrm{Ca}$ at higher temperatures. Dodd [1965] reported that the Sr content of Mytilus edulis and Mytilus californianus vary seasonally with temperature. Likewise, in the bivalve Mya arenaria, $\mathrm{Sr} / \mathrm{Ca}$ cycles positively corre- late with seasonality in the environment and most likely are governed by temperature [Palacios et al., 1994]. However, the results of Palacios et al. [1994] also indicate an ontogenetic effect related to growth rate and/or age. More recently, Gillikin et al. [2005] argue that $\mathrm{Sr} / \mathrm{Ca}$ in the aragonitic bivalve Saxidomus giganteus is mainly controlled by biological processes that affect biomineralization, and thus growth rate. These authors note a significant positive correlation between mean annual $\mathrm{Sr} / \mathrm{Ca}$ and growth rate, and a weak negative correlation between $\mathrm{Sr} / \mathrm{Ca}$ and temperature. A similar correlation between $\mathrm{Sr} / \mathrm{Ca}$ and growth rate was found in the aragonitic bivalve, Protothaca staminea [Takesue and van Geen, 2004]. However, no correlation was found between $\mathrm{Sr} / \mathrm{Ca}$ and growth rate or SST in Mercenaria mercenaria 


\section{Estimated temperature, $24 \mathrm{~m}$} measured temperature, $0 \mathrm{~m}$ buoy measured temperature, $24 \mathrm{~m}$ buoy

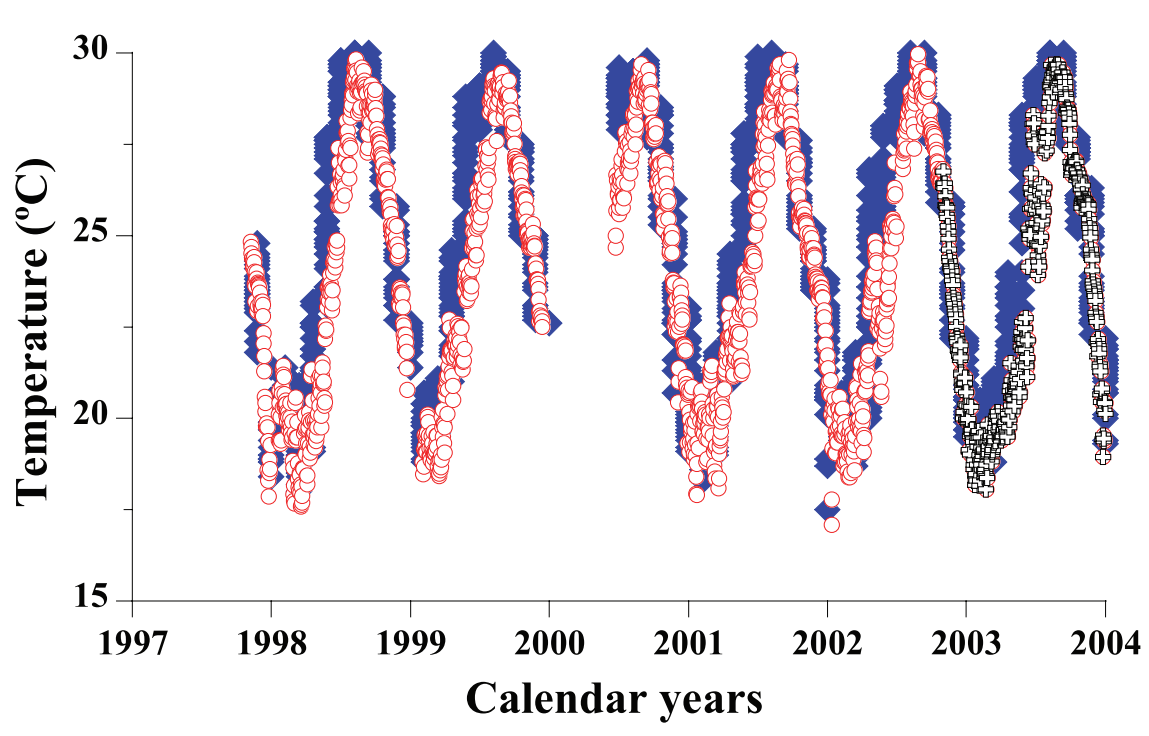

Figure 2. The $24 \mathrm{~m}$ temperature record (diamonds) from 1997 to 2004 estimated from a compilation of SSTs (circles) and a nearby 24 m record (crosses), in the Stetson Bank, the collection site of Conus shells used in this calibration.

[Gillikin et al., 2005], in contrast to the observations of Stecher et al. [1996]. The latter suggests that the biological imprint may vary among locations. In contrast with the observations of Gillikin et al. [2005] and Takesue and van Geen [2004], some studies have noted a negative correlation between growth rate and $\mathrm{Sr} / \mathrm{Ca}$, which they attribute to metabolic control on the composition of the extrapallial fluid. For example, Purton et al. [1999] observe in the aragonitic mollusks Venericardia planicosta and Clavilithes macrospira a trend of increased $\mathrm{Sr} / \mathrm{Ca}$ with the age-related decrease in growth rate. Also, Klein et al. [1996] note large differences in mean $\mathrm{Sr} / \mathrm{Ca}$ among different specimens of the calcitic bivalve Mytilus trossulus. In both studies, variations in $\mathrm{Sr} / \mathrm{Ca}$ are attributed to variable mantle metabolic activity. To overcome an ontogenetic/metabolic overprint, Goodwin et al. [2003] suggest using the juvenile portions of the bivalve record for paleoclimate reconstruction. These divergent observations for different species of aragonitic and calcitic mollusks attest to the complexity of using gastropod $\mathrm{Sr} / \mathrm{Ca}$ as a temperature proxy, due to differences in taxonomy, mineralogy, biometry, and morphology. The problem is further confounded by the fact that, at least on seasonal timescales, the two factors that potentially most influence $\mathrm{Sr} / \mathrm{Ca}$ ratios, temperature and growth rate, covary as organisms tend to grow slower and calcify less at lower temperatures [Lutz and Rhoads, 1980]. These studies highlight the need to define taxon- and growth-stage specific trace metal paleothermometers.

\section{Study Area and Samples}

[5] Four modern Conus ermineus shells were sampled from Stetson Bank in the Flower Garden Banks National Marine Sanctuary (FGBNMS) (U. S. Gulf of Mexico) (Figure 1). Two live specimens (FGS2 and FGS3) and one that died shortly after collection (FGS1) were collected on 29 May 2003. A fourth live specimen (FGS4) was collected on 4 September 2003. All samples were collected at water depths between 21 and 26 meters.

[6] Stetson Bank is a small clay/siltstone bank located $165 \mathrm{~km}$ south of the Texas-Louisiana border on the outer continental shelf. This bank is elevated $50 \mathrm{~m}$ above the seafloor and provides a habitat for a large fish community. The site is under the influence of the subtropical climatic regime and is strongly affected by the Gulf Stream. Large rivers and streams that flow into the Gulf of Mexico, most notably the MississippiAchafalya River system, cause large seasonal fluctuations in sea surface salinity from 32 to 
Table 1. Data for Size, Whorl Length, and Age for Conus Specimens ${ }^{\mathrm{a}}$

\begin{tabular}{lcccc}
\hline \multicolumn{1}{c}{ Specimen } & FGS1 & FGS2 & FGS3 & FGS4 \\
\hline Shell height, mm & 67 & 78 & 72 & 79 \\
Shell width, mm & 39 & 44 & 41 & 46 \\
Whorl length, mm & 320 & 385 & 369 & 360 \\
Estimated life span, years & 5.8 & 12 & 5.8 & 8.8 \\
\hline
\end{tabular}

${ }^{\mathrm{a}}$ Note that several years of growth are in each whorl.

36 psu. Increased springtime precipitation along the southern U. S. results in maximum river discharge and a coastal salinity minimum in the spring. High salinities are caused by upcoast (eastward) flow in the summer, which confines Mississippi-Achafalya discharge to the eastern Gulf. During nonsummer months downcoast (westward) flow carries this water to the Texas coast and shelf [LATEX, 1997].

[7] The upper water column structure at Stetson Bank changes seasonally. During spring and early summer, differences in temperature $\left(\sim 6^{\circ} \mathrm{C}\right)$ between the surface and $24 \mathrm{~m}$ in the water column are most pronounced because low salinity waters inhibit vertical mixing, and sea-surface warming precedes warming at depth by several months. Maximum SSTs occur in early August, whereas the maximum temperature at $24 \mathrm{~m}$ occurs in early September; minimum SSTs occur in early March.
In the winter, the water column is well-mixed and therefore temperatures are constant with depth at this site.

\section{Methods}

\subsection{Environmental Data From Stetson Bank}

[8] Hourly surface temperature and salinity recorded by automated recorders were collected at the sampling site from 29 October 2002 to 12 December 2003 and are available from Flower Gardens Banks National Marine Sanctuary (http:// flowergarden.noaa.gov/). Unfortunately, this temperature record does not cover the entire duration of shell growth for the collected specimens. To construct a longer record which overlaps our gastropod records, spanning $\sim 6-8$ years prior to the collection in May 2003, we use SST data from the nearby buoy \#42019 of the National Data Buoy Center (NDBC), $100 \mathrm{~km}$ west of Stetson Bank (http://www.ndbc.noaa.gov/index.shtml). NDBC buoy \#42019 records sea surface conditions, whereas our gastropods were collected at a depth of $\sim 24 \mathrm{~m}$. Because stratification can result in temperature differences of $6^{\circ} \mathrm{C}$ between the surface and $24 \mathrm{~m}$ during the mid-spring to summer interval, we apply an offset to the NDBC

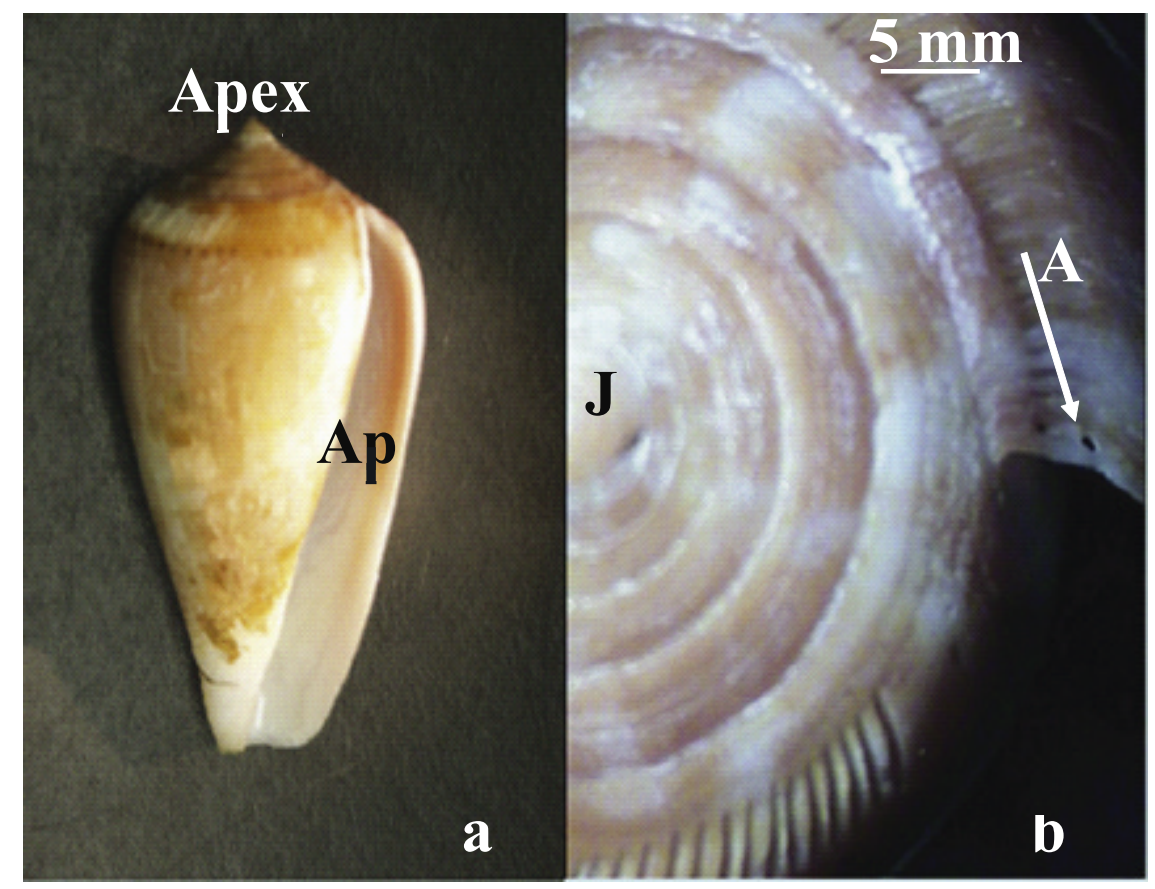

Figure 3. (a) Study specimen gastropod C. ermineus shell labeled from apex to aperture (Ap). (b) At a $1 \mathrm{~mm}$ sampling interval, samples were milled parallel to growth banding. The arrow indicates the direction of sampling. $\mathrm{J}$, juvenile; A, adult. 
surface record to estimate temperatures at $24 \mathrm{~m}$ for that year (LATEX, 1993). The offset is based on temperature differences between sea surface and $24 \mathrm{~m}$. The derived $24-\mathrm{m}$ temperature record is shown in Figure 2.

\subsection{Shell Sampling}

[9] Live Conus ermineus specimens were cleaned and polished with sandpaper at the spiral area of the cone shells to remove the periostracum, surface contamination, and encrusting organisms. Each sample was measured for height, width, and whorl length (linear distance from the apex to the aperture) to approximate age (Table 1). Live specimens were kept in aquaria following collection for observations and sampling. During sampling, the live specimens were removed from aquaria and wrapped in a wet towel for no longer than 20 minutes at a time. The shell surface and sampling drill were kept clean and dry with compressed air to prevent moisture intrusion and cross-contamination between samples. Linear sample grooves were milled parallel to growth banding using a $0.3-\mathrm{mm}$ Brasseler carbide drill bit (Figure 3). Initial sample intervals were $1 \mathrm{~mm}$ with a target resolution of 20 samples per annual cycle. We used $0.5-\mathrm{mm}$ sample intervals for slow growth intervals $\left(<20 \mathrm{~mm} \mathrm{yr}^{-1}\right)$. Each groove was milled to a size approximately $0.3 \mathrm{~mm}$ deep, $0.3 \mathrm{~mm}$ wide and $3 \mathrm{~mm}$ long, sufficient to provide $>500 \mu \mathrm{g}$ of $\mathrm{CaCO}_{3}$ powder. Half the powder from each sample was used for isotopic analysis and the other half for trace metal analysis. The dead specimen was sampled in a similar manner.

\subsection{Isotopic and Trace Metal Analyses}

[10] For isotopic analysis, each sample was converted to $\mathrm{CO}_{2}$ gas in a Finnigan Kiel II carbonate reaction system by adding " $100 \%$ " phosphoric acid at $70^{\circ} \mathrm{C}$. The gas was subsequently analyzed on a Finnigan MAT 251 isotope-ratio mass spectrometer. Replicates were run on every fifth sample, with values obtained to an analytical precision of $\pm 0.04 \%$ or $\delta^{13} \mathrm{C}$ and $\pm 0.07 \%$ for $\delta^{18} \mathrm{O}$. Results are reported relative to VPDB by calibration to the NBS-19 reference standard $\left(\delta^{13} \mathrm{C}=1.95 \%\right.$ VPDB, $\delta^{18} \mathrm{O}=-2.20 \%$ v VPB).

[11] For trace metal analyses, aragonite powder splits were progressively reacted with trace metal clean $0.065 \mathrm{~N} \mathrm{HNO}_{3}\left(\mathrm{SEASTAR}^{\circledR}\right)$, until complete dissolution was achieved. After a 10 minute centrifugation, $100 \mu \mathrm{l}$ of the sample solution was further diluted with $300 \mu \mathrm{l}$ of $0.5 \mathrm{~N} \mathrm{HNO}_{3}$ $\left(\right.$ SEASTAR $^{\mathrm{R}}$ ) to obtain a final $\mathrm{Ca}$ concentration
([Ca]) in the $\sim 4 \pm 1 \mathrm{mmol}$ range. The progressive dissolution and dilution procedure ensured that [Ca] were kept relatively constant in order to minimize matrix effects [Rosenthal et al., 1999]. The analytical method for measuring $\mathrm{Sr} / \mathrm{Ca}$ by a Vista-Pro CCD Radial ICP-OES is based on the method outlined by Andreasen et al. [2006]. Longterm precision for $\mathrm{Sr} / \mathrm{Ca}$, evaluated by repeatedly analyzing three consistency standard solutions in the range of 0.46 to $1.84 \mathrm{mmol} \mathrm{mol}^{-1}$ at the beginning and end of each run over the course of 3 years, is on average $\pm 1.5 \%$ (RSD).

\section{Results}

\section{1. $\mathrm{Sr} / \mathrm{Ca}$ and $\delta^{18} \mathrm{O}$ Records}

[12] Paired measurements of $\mathrm{Sr} / \mathrm{Ca}$ and $\delta^{18} \mathrm{O}$ are plotted as a function of distance from the apex (Figure 4). Depicted this way, specimen age increases with increasing length (to the right in Figure 4). All four gastropod records share several common features. First, in each record, $\mathrm{Sr} / \mathrm{Ca}$ and $\delta^{18} \mathrm{O}$ covary showing between 6 and 8 cycles. Second, in each individual shell, both the mean annual and seasonal range of $\delta^{18} \mathrm{O}$ are approximately constant throughout the record. In contrast, both the mean annual and seasonal amplitude of $\mathrm{Sr} / \mathrm{Ca}$ increase with age. For example, the mean $\mathrm{Sr} / \mathrm{Ca}$ ratio of FGS4 increases from about $1.4 \mathrm{mmol} \mathrm{mol}^{-1}$ near the apex to about $1.7 \mathrm{mmol} \mathrm{mol}{ }^{-1}$ close to the aperture, with a concomitant increase in the seasonal amplitude from 0.8 to $1.0 \mathrm{mmol} \mathrm{mol}^{-1}$. Third, there is a significant decrease in the width of the seasonal cycles with age (note that for FGS2 only the adult part of the shell was analyzed). Lastly, the $\delta^{18} \mathrm{O}$ display similar ranges of values in all four shells: from $-1.3 \%$ to $1.0 \%$ in FGS1, $-1.1 \%$ o to $1.3 \%$ in $\mathrm{FGS} 3,-1.2 \%$ to $1.4 \%$ in FGS4, and $-1.0 \%$ to $1.5 \%$ in FGS2 (excluding a single value of $2.1 \%$ that is likely an analytical artifact). There is significant variability in $\mathrm{Sr} / \mathrm{Ca}$ ratios among the four shells. $\mathrm{Sr} / \mathrm{Ca}$ ratios range from 0.86 to $2.03 \mathrm{mmol} \mathrm{mol}^{-1}$ in FGS1, 1.14 to $2.56 \mathrm{mmol} \mathrm{mol}^{-1}$ in FGS2, 0.98 to $2.10 \mathrm{mmol} \mathrm{mol}^{-1}$ in FGS3, and 1.02 to $3.01 \mathrm{mmol} \mathrm{mol}^{-1}$ for FGS4.

\subsection{The $\delta^{18} \mathrm{O}$-Based Age Model}

[13] An age model has been constructed to convert whorl length to a timescale. As temperature and $\delta^{18} \mathrm{O}$ are highly correlated $\left(\mathrm{R}^{2}=0.84\right.$, all shells), it is assumed that temperature is the primary control of the $\delta^{18} \mathrm{O}$ record with only a minor influence 

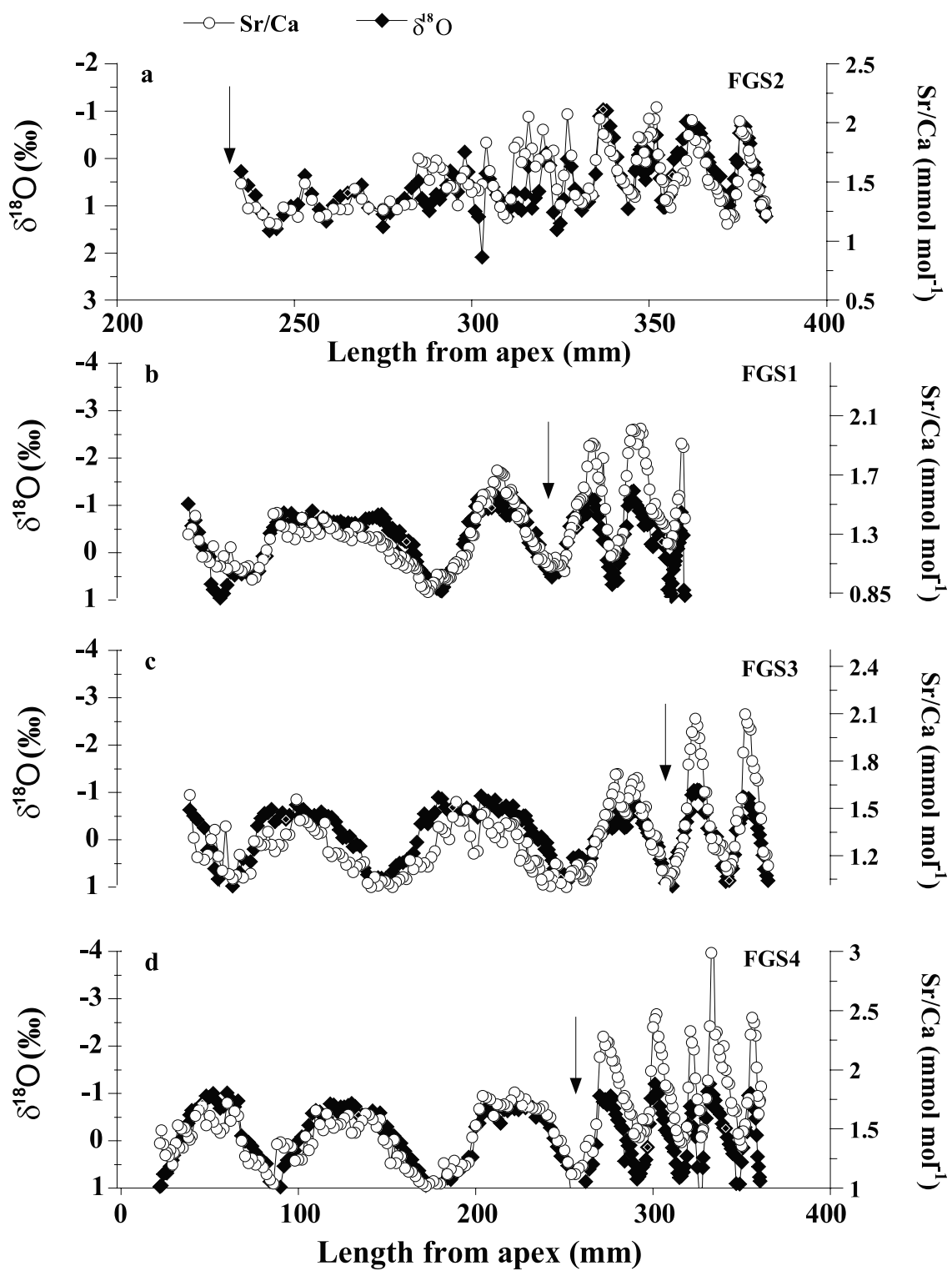

Figure 4. The $\delta^{18} \mathrm{O}$ and $\mathrm{Sr} / \mathrm{Ca}$ records versus distance from apex and toward the aperture for modern shells FGS2, FGS1, FGS3, and FGS4. Note that the $\delta^{18} \mathrm{O}$ scale has been inverted to correspond with temperature increasing upward, $\delta^{18} \mathrm{O}$ and $\mathrm{Sr} / \mathrm{Ca}$ scales are different in each panel, and $x$ scale for FGS2 is different from the other three shells. The arrow indicates our placement of the transition zone from juvenile to adult. Direction of increasing age is the right, and the entire record of FGS4 is not included.

from salinity (i.e., $\delta_{\omega}$ ) [Epstein et al., 1953; Grossman and Ku, 1986; Kobashi and Grossman, 2003; Gentry, 2005]. The highest and lowest $\delta^{18} \mathrm{O}$ values in the record represent peak winter and summer temperatures, respectively. Because FGS1-FGS3 shells were collected on 29 May 2003 and FGS4 on 24 September 2003, we assume that the $\delta^{18} \mathrm{O}$ maximum closest to the aperture coincides with early March 2003, whereas the preceding $\delta^{18} \mathrm{O}$ minimum is identified as early September 2002. This anchor point method, applied in previous studies [e.g., Klein et al., 1996; Paillard et al., 1996], is used to establish the chronology of each record (Figures 5a and 5b). Applying the $\delta^{18} \mathrm{O}$ age model to the $\mathrm{Sr} / \mathrm{Ca}$ record, $\mathrm{Sr} / \mathrm{Ca}$ ratios of all four records correlate positively with temperature. Although the correlation between individual $\mathrm{Sr} / \mathrm{Ca}$ records and temperature is good, the pooled correlation for all four records is not as good (Table 2). The cause of this discrepancy is the offset in mean $\mathrm{Sr} / \mathrm{Ca}$ among different records, which might be related to natural variability within 

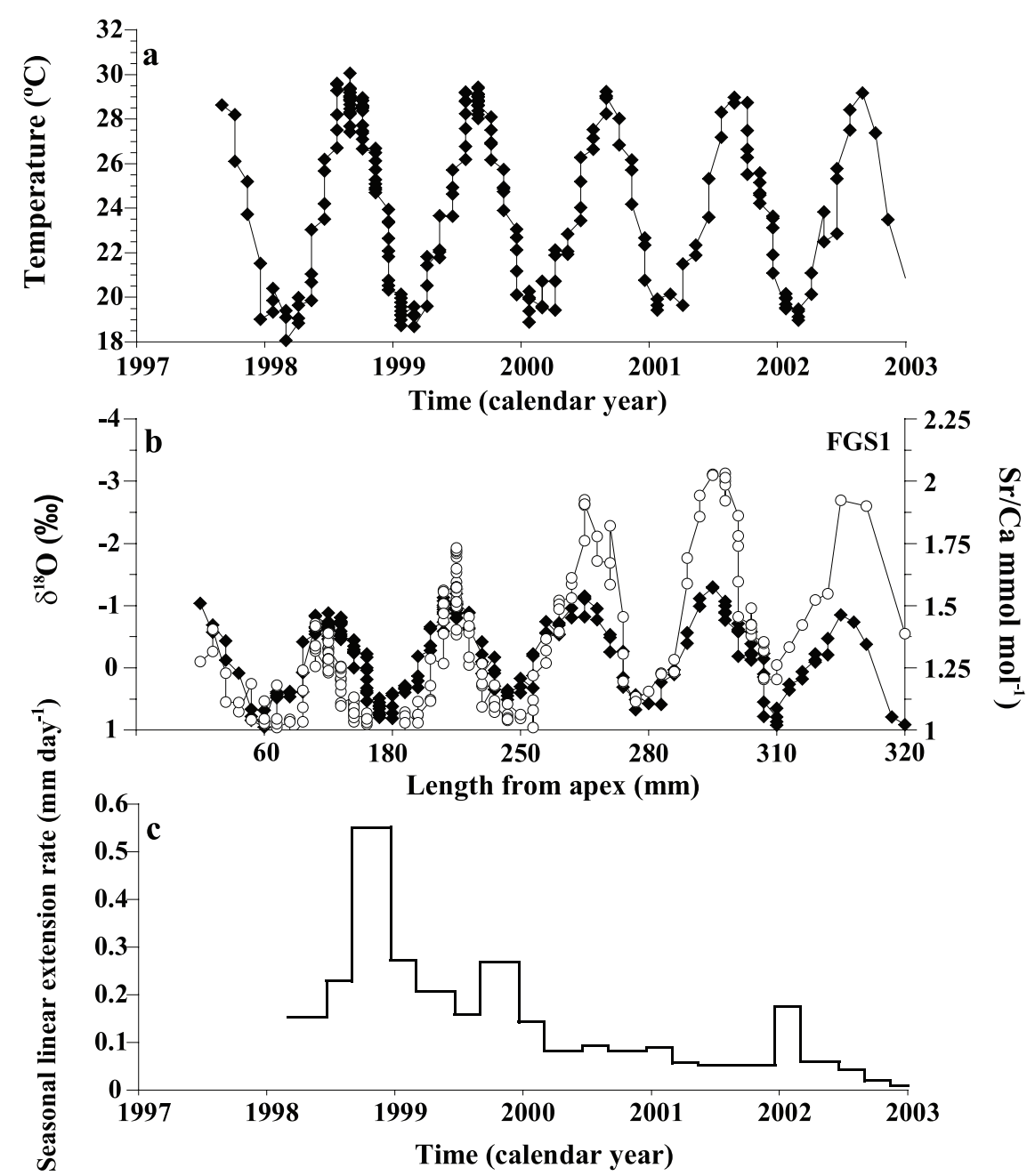

Figure 5. Example from FGS1 showing construction of the $\delta^{18} \mathrm{O}$ age model. (a) Temperature record versus calendar years from 1997 to 2003. (b) The $\delta^{18} \mathrm{O}$ and $\mathrm{Sr} / \mathrm{Ca}$ records from FGS1 versus length from the apex for corresponding years. Note that the $x$ axis for this plot is not linearly scaled. (c) Seasonal linear extension rate (LER) versus calendar years. Seasonal LERs are calculated from the distance between specific time points associated with $\delta^{18} \mathrm{O}$ extrema and the midpoints between these extrema. A seasonal variation in linear extension rate is evident in the juvenile growth stage.

species. To assess whether the correlation between $\mathrm{Sr} / \mathrm{Ca}$ and temperature could be improved, we tested an alternative age model based on tuning $\mathrm{Sr} / \mathrm{Ca}$ to temperature in a similar fashion as was done with $\delta^{18} \mathrm{O}$. Whereas the latter age model slightly improves the individual correlations of $\mathrm{Sr} / \mathrm{Ca}$ with temperature, there is no significant improvement for the pooled data; $\mathrm{R}^{2}$ for the pooled data is 0.27 and 0.29 for the $\delta^{18} \mathrm{O}$ and $\mathrm{Sr} / \mathrm{Ca}$ age models, respectively (Table 2). Therefore, in the following discussion we use the $\delta^{18} \mathrm{O}$ age model.

\subsection{Linear Extension Rates}

[14] Using the $\delta^{18} \mathrm{O}$ age model, we calculate linear extension rates (LER) (seasonal and mean annual) for each shell to determine if variations in exten- sion rate affect the relationship between $\mathrm{Sr} / \mathrm{Ca}$ and temperature. LER specifies the measured spiral length, between seasonal and annual tie points, with respect to time. For instance, mean annual LER is calculated from the distance between two annual extrema (i.e., the distance between two subsequent winter peaks). Note that LER is not directly proportional to calcification rate because shell length and wall thickness increase with ontogeny. Lorrain et al. [2005] used sclerochronology to determine the daily production of "surface of material" to quantify potential kinetic effects in the $\mathrm{Sr} / \mathrm{Ca}$ of bivalve calcite. They suggest that the amount of $\mathrm{CaCO}_{3}$ precipitated influences $\mathrm{Sr} / \mathrm{Ca}$ ratios more than LER. In this study, LER is a rough estimate of growth rate and cannot be extended to calculate precipitation rate or the 
Table 2. Coefficients of Determination $\mathrm{R}^{2}$ From $\mathrm{Sr} / \mathrm{Ca}$ and $\delta^{18} \mathrm{O}$ Versus Temperature for the $\delta^{18} \mathrm{O}$ and $\mathrm{Sr} / \mathrm{Ca}$ Age Models

\begin{tabular}{ccc}
\hline Specimen & $\begin{array}{c}\delta^{18} \mathrm{O} \text { Age Model } \\
\text { Temperature }\end{array}$ & $\begin{array}{c}\text { Sr/Ca Age Model } \\
\text { Temperature }\end{array}$ \\
\hline $\mathrm{FGS} 1$ & & \\
$\mathrm{Sr} / \mathrm{Ca}$ & $\mathbf{0 . 4 1}$ & $\mathbf{0 . 4 6}$ \\
$\delta^{18} \mathrm{O}$ & 0.80 & 0.83 \\
$\mathrm{FGS} 2$ & & \\
$\mathrm{Sr} / \mathrm{Ca}$ & $\mathbf{0 . 6 8}$ & $\mathbf{0 . 8 0}$ \\
$\delta^{18} \mathrm{O}$ & 0.71 & 0.80 \\
$\mathrm{FGS3}$ & & \\
$\mathrm{Sr} / \mathrm{Ca}$ & $\mathbf{0 . 3 7}$ & $\mathbf{0 . 3 6}$ \\
$\delta^{18} \mathrm{O}$ & 0.83 & 0.83 \\
$\mathrm{FGS} 4$ & & $\mathbf{0 . 6 7}$ \\
$\mathrm{Sr} / \mathrm{Ca}$ & $\mathbf{0 . 5 6}$ & 0.83 \\
$\delta^{18} \mathrm{O}$ & 0.66 & $\mathbf{0 . 2 9}$ \\
$\mathrm{Pooled}$ & & 0.82 \\
$\mathrm{Sr} / \mathrm{Ca}$ & $\mathbf{0 . 2 7}$ & \\
$\delta^{18} \mathrm{O}$ & 0.74 & \\
\hline
\end{tabular}

surface area of $\mathrm{CaCO}_{3}$ precipitated. As the Conus shell grows, internal dissolution of the penultimate whorl occurs and shell material is added to the last whorl for defense against predators [Kohn et al., 1979]. The remodeling of the shell as the gastropod ages makes it difficult to constrain surface area changes; therefore LER is only an approximation of growth rate. Two different stages of annual linear extension are evident: juvenile and adult (Figure 6). The juvenile stage is marked by a fast LER ( $>50 \mathrm{~mm} \mathrm{yr}^{-1}$ ) and typically extends over the first three years. LER during the adult stage is slower $\left(<50 \mathrm{~mm} \mathrm{yr}^{-1}\right)$. Note that FGS1, FGS3, and FGS4 were sampled from the juvenile to adult stages and therefore have similar growth patterns, whereas FGS2 includes only the slow-growing adult record of the shell. Mean annual $\mathrm{Sr} / \mathrm{Ca}$ increases as LER decreases as seen in shells FGS1, FGS3, and FGS4 (Figure 7). Here we refer to the age-related decrease in mean annual LER

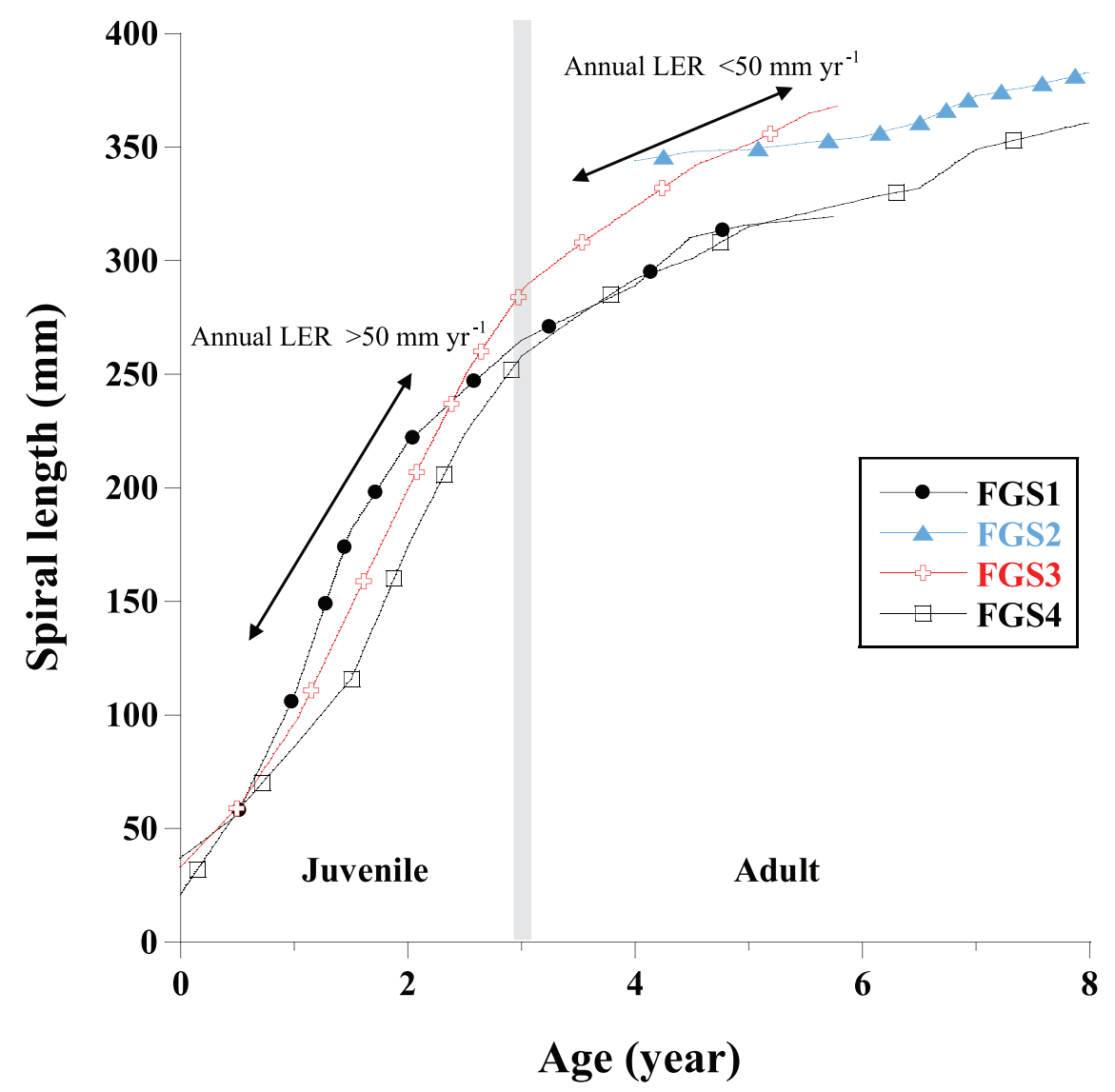

Figure 6. Mean annual linear extension rate (LER) as a function of length along the spiral for specimens. Mean annual LER is calculated from the distance between two annual extrema (i.e., the distance between two subsequent winter peaks). On the basis of the variation of growth rate with age, two stages of growth were identified: juvenile and adult. The shaded region marks an adolescent zone, where the gastropod transitions from juvenile to adult. Typically, the juvenile period is the first three years of growth followed by the adult. Note that only the adult portion of FGS2 was sampled. 


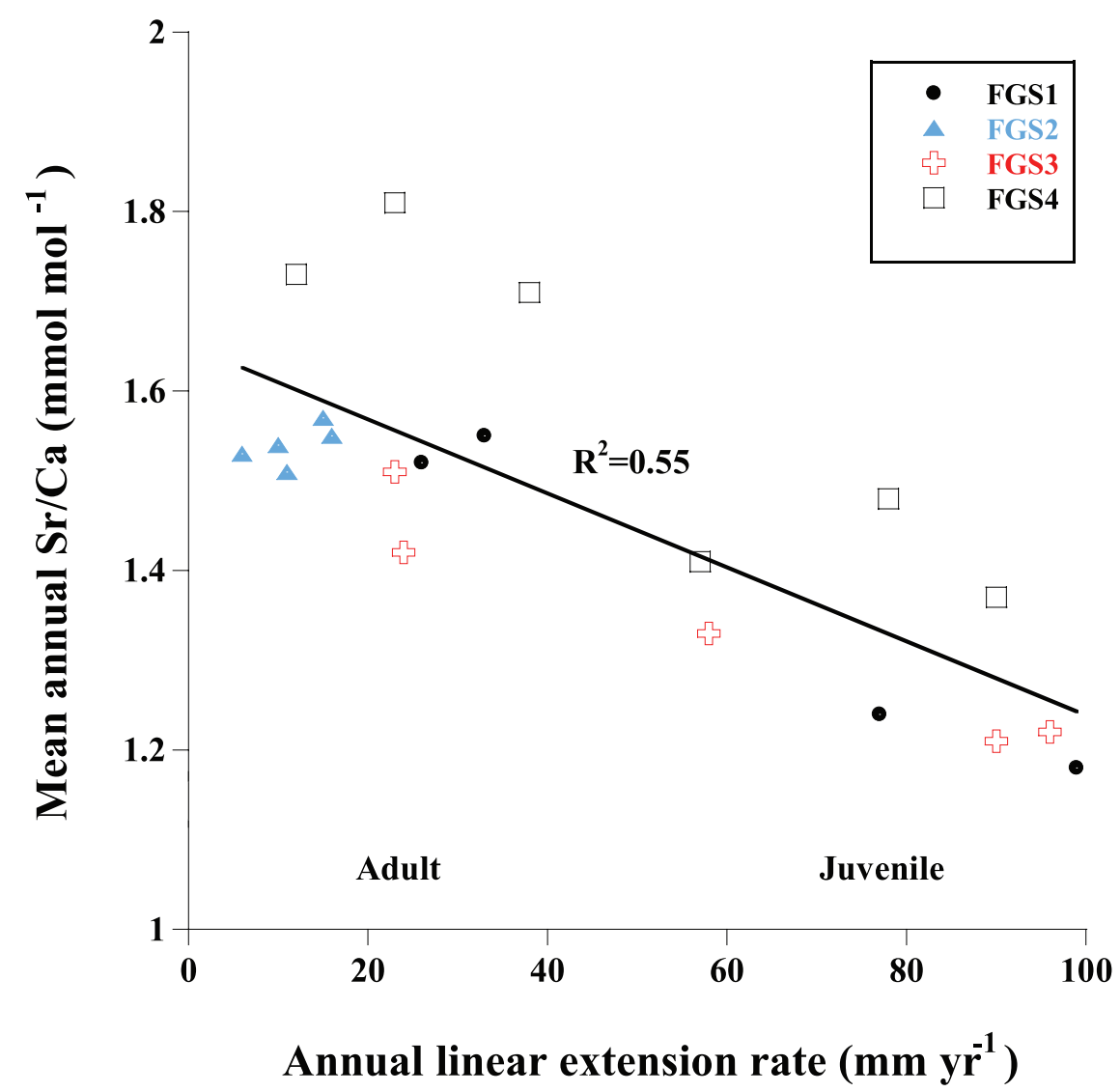

Figure 7. (a) Average annual $\mathrm{Sr} / \mathrm{Ca}$ ratios (from data in Figure 4) versus annual linear extension rates. Annually averaged $\mathrm{Sr} / \mathrm{Ca}$ ratios are correlated with annual extension rate $\left(\mathrm{R}^{2}=0.55\right)$. Compiled from four modern shells: FGS1 (circles), FGS2 (triangles), FGS3 (crosses), and FGS4 (squares).

and concomitant increase in mean annual $\mathrm{Sr} / \mathrm{Ca}$ as the ontogenetic effect.

[15] Seasonal LERs are calculated from the distance between specific time points associated with $\delta^{18} \mathrm{O}$ extrema and the midpoints between these extrema. Hence each interval represents about a 3-month growth period. In the juvenile parts of the records, $\delta^{18} \mathrm{O}$ and $\mathrm{Sr} / \mathrm{Ca}$ peaks are wider for the summer months than for the winter months, indicating seasonal variability in LER (Figure 5). Seasonal variability in LER is less marked in the adult portion of the record, and is superimposed on a overall trend of decreasing LER through the mollusk's life (Figure 5). This is consistent with other studies which suggested that the growth rate of some bivalve species slows considerably and the spacing between annual peaks decreases with age [Stecher et al., 1996; Gillikin et al., 2005]. On seasonal timescales $\mathrm{Sr} / \mathrm{Ca}$ positively covaries with changes in seasonal LER; $\mathrm{Sr} / \mathrm{Ca}$ is high during the summer when LER is high and low during the winter when LER is low. Note however that although there is an apparent decrease in mean annual and seasonal variability of LER (within the resolution of the sampling) the seasonal $\mathrm{Sr} / \mathrm{Ca}$ cycle remains relatively constant or slightly increases with age (i.e., $\mathrm{Sr} / \mathrm{Ca}$ is also high when growth slows with ontogeny).

\section{Discussion}

[16] The $\delta^{18} \mathrm{O}$ data from all four gastropods shells are inversely correlated with temperature yielding a slope of $\Delta \delta^{18} \mathrm{O} / \Delta \mathrm{T}=0.19 \pm 0.01\left(\mathrm{R}^{2}=0.84\right)$. The calculated sensitivity of $0.19 \%$ per ${ }^{\circ} \mathrm{C}$ is close to the experimental relationship of $0.23 \%$ o per ${ }^{\circ} \mathrm{C}$ for aragonite [Grossman and $\mathrm{Ku}, 1986$ ]. The apparent consistency between these two results suggests that temperature is the dominant control on $\delta^{8} \mathrm{O}$ in the shells, whereas salinity-related variability in $\delta_{\omega}$ influences the $\delta^{18} \mathrm{O}$ record to a lesser extent [Gentry, 2005]. The latter is likely the main cause for the small, albeit significant, discrepancy between the gastropod and Grossman and $K u$ [1986] temperature sensitivity values. 
Table 3. Statistics of $\delta^{18} \mathrm{O}-\mathrm{Sr} / \mathrm{Ca}$ and $\mathrm{Sr} / \mathrm{Ca}-\mathrm{T}$ Regressions for Individual and Pooled Sr/Ca Data for Juvenile Portions, Adult Portions, and the Entire Record ${ }^{\mathrm{a}}$

\begin{tabular}{|c|c|c|c|c|c|c|c|c|c|c|c|c|c|}
\hline \multirow[b]{2}{*}{ Calibration } & \multicolumn{3}{|c|}{ FGS1 } & \multirow{2}{*}{$\frac{\mathrm{FGS} 2}{\mathrm{~A}}$} & \multicolumn{3}{|c|}{ FGS3 } & \multicolumn{3}{|c|}{ FGS4 } & \multicolumn{3}{|c|}{ Pooled } \\
\hline & All & $\mathrm{J}$ & A & & All & $\mathrm{J}$ & A & All & $\mathrm{J}$ & A & All & $\mathrm{J}$ & A \\
\hline \multicolumn{14}{|l|}{$\delta^{18} \mathrm{O}-\mathrm{Sr} / \mathrm{Ca}$} \\
\hline $\mathrm{m}$ & -0.35 & -0.30 & -0.43 & -0.37 & -0.31 & -0.24 & -0.47 & -0.36 & -0.28 & -0.47 & -0.30 & -0.26 & -0.40 \\
\hline $\mathrm{b}$ & 1.28 & 1.13 & 1.36 & 1.58 & 1.29 & 1.25 & 1.44 & 1.58 & 1.40 & 1.82 & 1.38 & 1.26 & 1.59 \\
\hline $\mathrm{R}^{2}$ & 0.54 & 0.72 & 0.68 & 0.80 & 0.54 & 0.52 & 0.85 & 0.41 & 0.67 & 0.71 & 0.33 & 0.47 & 0.51 \\
\hline \multicolumn{14}{|l|}{$\mathrm{Sr} / \mathrm{Ca}-\mathrm{T}$} \\
\hline $\mathrm{m}$ & 0.046 & 0.044 & 0.081 & 0.061 & 0.042 & 0.034 & 0.082 & 0.053 & 0.048 & 0.085 & 0.047 & 0.042 & 0.072 \\
\hline $\mathrm{b}$ & 0.17 & 0.12 & -0.41 & 0.10 & 0.30 & 0.42 & -0.45 & 0.30 & 0.23 & -0.21 & 0.26 & 0.24 & -0.05 \\
\hline $\mathrm{R}^{2}$ & 0.37 & 0.64 & 0.76 & 0.77 & 0.37 & 0.45 & 0.75 & 0.28 & 0.62 & 0.63 & 0.28 & 0.66 & 0.68 \\
\hline
\end{tabular}

${ }^{\mathrm{a}} \mathrm{J}$, juvenile portions; A, adult portions; All, entire record. Note only adult portions of FGS2 were sampled. Included are slope (m), intercept (b) from the linear equation $(y=m x+b)$, and coefficient of determination $\left(R^{2}\right)$.

[17] Temperature control on Sr uptake into aragonite has been noted in inorganic laboratory precipitates [Kinsman and Holland, 1969], corals [Weber, 1973], and scelerosponges [Rosenheim et al., 2004]. In these cases, $\mathrm{Sr} / \mathrm{Ca}$ ratios exhibit an inverse relationship with temperature, which is consistent with thermodynamic expectations. In contrast, our data show a positive correlation between gastropod $\mathrm{Sr} / \mathrm{Ca}$ and temperature. Other studies of biogenic aragonite have also noted a positive relationship between $\mathrm{Sr} / \mathrm{Ca}$ and temperature: the aragonitic foraminifer Hoeglundina elegans [Rosenthal et al., 2006], turritellid gastropods [Tripati and Zachos, 2000], and bivalves [Dodd, 1965; Stecher et al., 1996; Takesue and van Geen, 2004; Gillikin et al., 2005]. However, there is no apparent relationship between temperature and $\mathrm{Sr} / \mathrm{Ca}$ in freshwater aragonitic gastropods [Buchardt and Fritz, 1978]. Thus, in contrast with coral $\mathrm{Sr} / \mathrm{Ca}$ variations, gastropod shells are likely driven by the influence of temperature on biological processes (e.g., calcification rate or growth rate) rather than a thermodynamic effect on the distribution coefficient. Zhong and Mucci [1989] show in inorganic precipitation experiments that the distribution coefficient for $\mathrm{Sr}$ uptake in aragonite is independent of precipitation rate. Therefore the growth rate related Sr incorporation mechanism has to be principally biological, either on the mineralization front [Gillikin et al., 2005] or during ion transport from the surrounding medium into the extrapallial fluid [Klein et al., 1996]. Metabolic models of Sr incorporation suggest that $\mathrm{Sr} / \mathrm{Ca}$ should be inversely related to growth rate, as seen in corals [Cohen et al., 2001; Ferrier-Pages et al., 2002; Cohen and McConnaughey, 2003]. Contrary to most bivalve studies, which demonstrate a positive correlation between $\mathrm{Sr} / \mathrm{Ca}$ and growth rate, gastropod shells of the Conus species conform to the expected relationship of the metabolic models. We contend that the relationship between $\mathrm{Sr} / \mathrm{Ca}$ and temperature is likely driven by temperature influence on growth rate.

[18] The partition coefficient $\mathrm{D}_{\mathrm{Sr}}$ for Conus gastropods varies from 0.1 at $18^{\circ} \mathrm{C}$ to 0.3 at $30^{\circ} \mathrm{C}$ (where $\left.\mathrm{D}_{\mathrm{Sr}}=(\mathrm{Sr} / \mathrm{Ca})_{\text {shell }} /(\mathrm{Sr} / \mathrm{Ca})_{\text {seawater }}\right)$. These values are comparable to the $\mathrm{D}_{\mathrm{Sr}}$ for $H$. elegans for the same temperature range [Rosenthal et al., 2006], but are much lower than those obtained in coralline and inorganic aragonites $(\sim 1)$. This discrepancy supports our assumption that the relationship between temperature and $\mathrm{Sr} / \mathrm{Ca}$ is mediated by biological processes. Given biological mediation, how constant is the relationship between $\mathrm{Sr} / \mathrm{Ca}$ and temperature? The answer to this question determines the usefulness of gastropod $\mathrm{Sr} / \mathrm{Ca}$ for paleotemperature reconstruction. Below we evaluate the fidelity of the relationship between $\mathrm{Sr} / \mathrm{Ca}$ in Conus shells and temperature and LER.

[19] Correlation among $\delta^{18} \mathrm{O}, \mathrm{Sr} / \mathrm{Ca}$, and temperature are significant for most juvenile and adult portions of Conus shells, using both individual and pooled data $\left(\mathrm{R}^{2}>0.50\right)$, and show that $\mathrm{Sr} / \mathrm{Ca}$ covaries with temperature. However, juvenile and adult stages yield $\mathrm{Sr} / \mathrm{Ca}-\delta^{18} \mathrm{O}$ and $\mathrm{Sr} / \mathrm{Ca}$-temperature relations with different slopes and y-intercepts, indicating that juvenile and adult shells have different sensitivities to temperature (Table 3). Offset in the slope and intercept among the four $\mathrm{Sr} / \mathrm{Ca}$ temperature relations is related to the ontogenetic effect on $\mathrm{Sr} / \mathrm{Ca}$ and different $\mathrm{Sr} / \mathrm{Ca}$ sensitivities to temperature among specimens. These are the main causes for the low correlation coefficient for the pooled $\mathrm{Sr} / \mathrm{Ca}$ data set. 

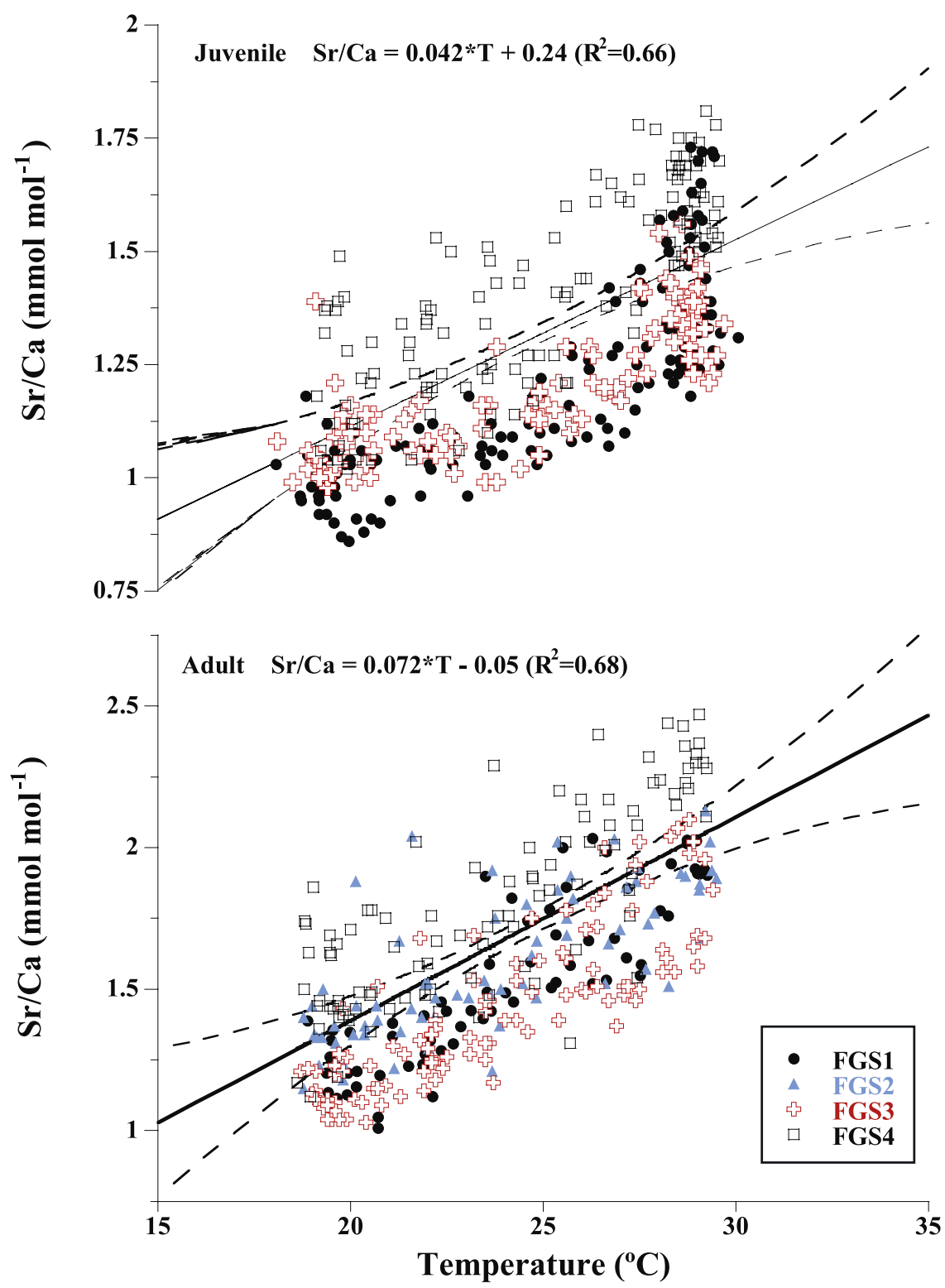

Figure 8. Regressions of the juvenile and adult $\mathrm{Sr} / \mathrm{Ca}$ ratios versus temperature. The $95 \%$ confidence intervals (dashed lines) are plotted. Note the regressions are significantly different within $2 \sigma$. Compiled from four modern shells FGS1 (circles), FGS2 (triangles), FGS3 (crosses), and FGS4 (squares).

[20] Above, we have shown that variations in LER occur throughout the gastropod's life as a function of age and also seasonally, particularly during the juvenile stage. For seasonal variations, a positive relationship is observed between LER and $\mathrm{Sr} / \mathrm{Ca}$ values, in contrast with the negative correlation for the ontogenetic trend. This discrepancy suggests that seasonal and long-term (ontogenetic) $\mathrm{Sr} / \mathrm{Ca}$ variability is likely controlled by different mineralization mechanisms, and that the seasonal variability is more closely related to temperature.
Therefore we use the seasonal $\mathrm{Sr} / \mathrm{Ca}$ signal to construct a temperature calibration.

\section{Temperature Calibration}

[21] To minimize growth rate effects on the temperature calibration, we treat the data in the following ways before calculating the regression equations: (1) Divide each record into juvenile and adult portions to account for the increase in mean annual $\mathrm{Sr} / \mathrm{Ca}$ and seasonal amplitude with age, and (2) omit the first half year of juvenile 


\section{$\longrightarrow$ Estimated temperature at $24 \mathrm{~m}$ \\ Juvenile \\ $\longrightarrow$ - Adult \\ Estimated mean annual temperature at $24 \mathrm{~m}$ \\ Mean annual temperature}

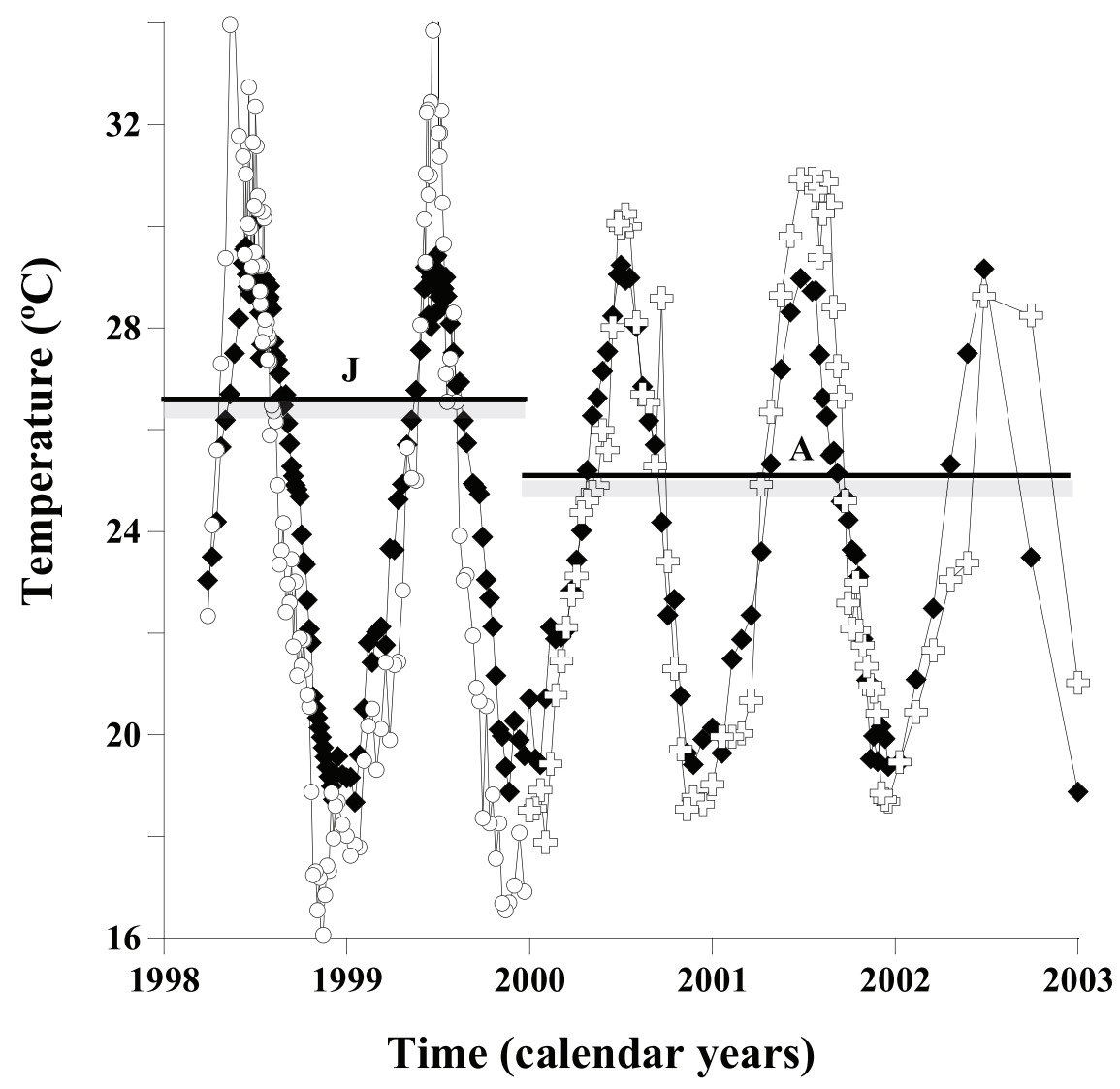

Figure 9. Temperature versus time in calendar years plotted for the estimated temperature at $24 \mathrm{~m}$ (diamonds) and juvenile (circles) and adult (crosses) temperature records. Note the juvenile and adult calibrations were applied to the FGS1 Sr/Ca record (omitted from calibration). Lines (A and J) indicate the mean annual temperature for the juvenile and adult temperature reconstructions. Shaded regions indicate the estimated mean annual temperature at $24 \mathrm{~m}$ for these portions.

growth to remove $\mathrm{Sr} / \mathrm{Ca}$ variability associated with early stages of shell development. We find that treating the data this way yields more accurate temperature estimates than a multivariate regression of $\mathrm{Sr} / \mathrm{Ca}$, temperature, and growth rate. We propose two calibration equations, one for the juvenile and another for the adult stage. We use geometric mean regression (model II) of $\mathrm{Sr} / \mathrm{Ca}$ against temperature [Laws, 1997]. Using the geometric mean method, which normalizes the data to a zero intercept and equally weights errors in both variables, allows us to pool data from all samples despite the offset in intercept among the four shells (for examples, see Rosenthal and Lohmann [2002] and Anand et al. [2003]). The temperature (T) calibrations for all specimens are described by (Figure 8):

Juvenile:

$$
\begin{aligned}
\mathrm{Sr} / \mathrm{Ca}\left(\mathrm{mmol} \mathrm{mol}^{-1}\right)= & 0.042( \pm 0.008) * \mathrm{~T}\left({ }^{\circ} \mathrm{C}\right) \\
& +0.24( \pm 0.21) \quad\left(\mathrm{R}^{2}=0.66\right)
\end{aligned}
$$

Adult:

$$
\begin{aligned}
\mathrm{Sr} / \mathrm{Ca}\left(\mathrm{mmol} \mathrm{mol}^{-1}\right)= & 0.072( \pm 0.014) * \mathrm{~T}\left({ }^{\circ} \mathrm{C}\right) \\
& -0.05( \pm 0.34) \quad\left(\mathrm{R}^{2}=0.68\right)
\end{aligned}
$$


[22] Using ANOVA, we calculate the standard deviations $( \pm 2 \sigma)$ of the slope and intercept. The juvenile and adult calibrations are significantly different beyond the $95 \%$ confidence interval of the calibration. The two calibrations are offset from each other due to the ontogenetic effect, which is not entirely eliminated by separating the record into juvenile and adult portions because variations in the seasonal amplitude within each growth stage are still present. There is relatively large scatter around the regression lines. Some of the scatter in the calibration might be related to (1) error in the chronology of the $\mathrm{Sr} / \mathrm{Ca}$ relative to the temperature record; (2) drilling the spire at different depths leading to sampling aragonite deposited at different stages of growth; (3) instrumental error $\left( \pm 0.07^{\circ} \mathrm{C}\right)$; (4) error in the compilation of the temperature record, especially in converting SSTs to 24-m temperatures $\left( \pm 0.5^{\circ} \mathrm{C}\right)$; and (5) vertical migration during the gastropod's life. For example, a migration of $\pm 4 \mathrm{~m}$ from the collection depth of $24 \mathrm{~m}$ would result in a $\pm 0.7^{\circ} \mathrm{C}$ change and an $0.07 \mathrm{mmol}$ $\mathrm{mol}^{-1}$ increase in $\mathrm{Sr} / \mathrm{Ca}$. These uncertainties account for some of the scatter in our records, but the effects are likely small.

[23] To test the applicability of $\mathrm{Sr} / \mathrm{Ca}$ paleothermometry we use three (FGS2, FGS3, FGS4) of the four records to construct new calibration equations and then apply them to a fourth record (FGS1), which is excluded from and thus independent of the calibration. This is done for each combination of shells except for FGS2, which was sampled only in the adult portion. For each combination of shells, the juvenile and adult calibration equations are comparable to the calibrations for all four shells within $2 \sigma$ and $3 \sigma$, respectively. The juvenile $\mathrm{Sr} / \mathrm{Ca}-$ temperature calibration is applied to the juvenile portion of the FGS1 $\mathrm{Sr} / \mathrm{Ca}$ record and the adult calibration to the adult portion. Thereafter, the two temperature reconstructions are spliced together to form a composite temperature record (Figure 9). For this case study, the juvenile and adult temperature reconstruction accurately resolves the mean annual temperature (MAT) at $24 \mathrm{~m}$ within $\pm 1^{\circ} \mathrm{C}$ for both juvenile and adult stages. However, estimates of the seasonal temperature amplitude are only accurate within $\pm 3.5^{\circ} \mathrm{C}$. The application of the model to other case studies, FGS3 and FGS4, resolves the MAT within $\pm 1.5^{\circ} \mathrm{C}$ and $\pm 1{ }^{\circ} \mathrm{C}$, and the seasonal temperature amplitude within $\pm 4^{\circ} \mathrm{C}$ and $\pm 3.5^{\circ} \mathrm{C}$, respectively.

[24] We test whether combining records from multiple shells to generate an average temperature record improves the accuracy of temperature esti- mates. For example, we average two years of coarsely sampled $\mathrm{Sr} / \mathrm{Ca}$ values among the four shells, then applied the $\mathrm{Sr} / \mathrm{Ca}$-temperature calibration to this smoothed two yearlong record. We calculate the pooled average by choosing two cycles from each growth stage that coincide among the shells and resample each record at $0.1 \mathrm{yr}$ interval. Subsequently, we combine the resampled $\mathrm{Sr} / \mathrm{Ca}$ records and separate the record into juvenile and adult stages. The adult temperature reconstruction captures the mean annual temperature and seasonal range of the in situ temperature record within $\pm 1^{\circ} \mathrm{C}$. The juvenile reconstruction resolves the mean annual temperature within $\pm 1^{\circ} \mathrm{C}$, but the seasonal temperature range only to about $\pm 4^{\circ} \mathrm{C}$ (Figure 10). This approach looks promising but needs to be further tested.

\section{Summary and Conclusions}

[25] This study assesses the potential of using $\mathrm{Sr} / \mathrm{Ca}$ ratios in the marine gastropod Conus ermineus for reconstructing sea surface temperature. Mollusk shells are potentially a very useful archive of paleoclimate, as their relatively fast growth rate provides seasonally resolved records of environmental changes. Results of this study show that $\mathrm{Sr} / \mathrm{Ca}$ and $\delta^{18} \mathrm{O}$ in the marine gastropod C. ermineus covary with the seasonal cycle of in situ water temperature. The seasonal variability is superimposed on a longterm trend of increasing $\mathrm{Sr} / \mathrm{Ca}$ with age that is not related to changes in water temperature. These changes in elemental ratios occur in association with changes in the shell linear extension rate (LER, used here as an indicator of growth rate); LER exhibits cyclic seasonal variability superimposed on a longterm decrease with age (ontogenetic effect). The positive correlation between $\mathrm{Sr} / \mathrm{Ca}$ and the seasonal temperature variability is in contrast with expectations from thermodynamics, inorganic precipitate experiments, and the behavior of $\mathrm{Sr}$ in coralline aragonite. This suggests that $\mathrm{Sr} / \mathrm{Ca}$ variations are likely correlated with temperature through temperature influence on growth rate, rather than a thermodynamic control on the distribution coefficient. The fact that seasonal variations in $\mathrm{Sr} / \mathrm{Ca}$ are positively correlated with growth rate, in contrast with the negative correlation for the ontogenetic trend, suggests that $\mathrm{Sr} / \mathrm{Ca}$ variability is not controlled by growth rate alone, but by two different biomineralization mechanisms. Of these, only the seasonal $\mathrm{Sr} / \mathrm{Ca}$ variability is related to temperature. 

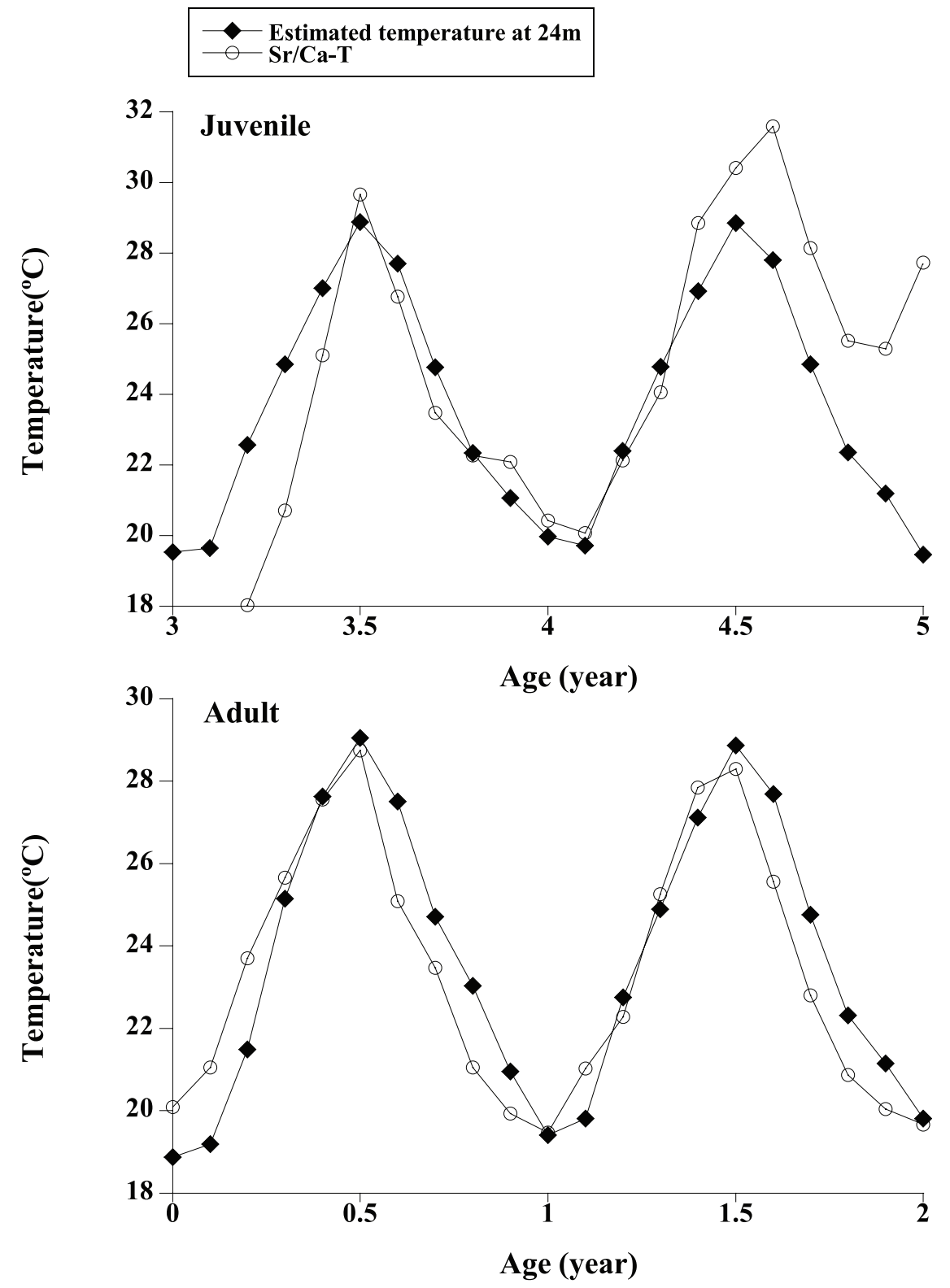

Figure 10. Pooled average juvenile and adult temperature reconstructions compared with the in situ temperature record. Note that the juvenile and adult reconstructions accurately reproduce the mean annual temperature of the in situ record, while the juvenile does not resolve the seasonal temperature variation.

[26] We explored the utility of $\mathrm{Sr} / \mathrm{Ca}$ for reconstructing sea surface temperature using four gastropod records. Our findings show that even after accounting for differences in juvenile and adult $\mathrm{Sr}$ incorporation, application of the calibration to a single specimen resolves the mean annual temperature within $\pm 1^{\circ} \mathrm{C}$ of the in situ temperature record, but overestimates seasonal temperature amplitude by $\pm 3.5^{\circ} \mathrm{C}$. The latter reflects the large variability in the seasonal $\mathrm{Sr} / \mathrm{Ca}$ record among specimens. This variability is most likely due to variable growth rate effects among individual specimens. To improve the accuracy of the calibration, we propose using a combination of multiple shells to produce an average temperature record. This multispecimen approach resolves the mean annual temperature within $< \pm 1^{\circ} \mathrm{C}$ for both juvenile and adult calibration, and seasonal temperature amplitude within $\pm 1{ }^{\circ} \mathrm{C}$ for the adult calibration.

[27] The results presented here suggest that the $\mathrm{Sr} / \mathrm{Ca}$-temperature calibration in $C$. ermineus shells has the potential to reconstruct changes in mean annual temperature and seasonality in the past. This relationship is, however, influenced by biological processes linking temperature to 
growth rate. Therefore caution should be taken before applying this calibration, as the relationship, which is biologically mediated, may be both spatially and temporally variable.

\section{Acknowledgments}

[28] Reviews by David P. Gillikin and Renee Takesue greatly improved this manuscript. This study was supported by the National Science Foundation grants EAR-0126173 (Y.R. and C.H.L.) and EAR-0126311 (E.L.G.) and the Leverhulme Trust (C.H.L.).

\section{References}

Anand, P., H. Elderfield, and M. H. Conte (2003), Calibration of $\mathrm{Mg} / \mathrm{Ca}$ thermometry in planktonic foraminifera from a sediment trap time series, Paleoceanography, 18(2), 1050, doi:10.1029/2002PA000846.

Andreasen, D. H., S. Sosdian, S. Perron-Cashman, C. Lear, T. deGaridel-Thoron, P. Field, and Y. Rosenthal (2006), Fidelity of radially viewed ICP-OES and magnetic-sector ICP-MS measurement of $\mathrm{Mg} / \mathrm{Ca}$ and $\mathrm{Sr} / \mathrm{Ca}$ ratios in marine biogenic carbonates: Are they trustworthy together?, Geochem. Geophys. Geosyst., 7, Q10P18, doi:10.1029/2005GC001124.

Andreasson, F., and B. Schmitz (1998), Tropical Atlantic seasonal dynamics in the early middle Eocene from stable oxygen and carbon isotope profiles of mollusc shells, Paleoceanography, 13, 183-192.

Beck, W. J., L. R. Edwards, E. Ito, F. W. Taylor, J. Recy, F. Rougerie, P. Joannot, and C. Henin (1992), Sea-surface temperature from coral skeletal strontium/calcium ratios, Science, 257, 644-647.

Buchardt, B., and P. Fritz (1978), Strontium uptake in shell aragonite from the freshwater gastropod Limnaea stagnalis, Science, 199, 291-292.

Cohen, A. L., and T. A. McConnaughey (2003), Geochemical perspectives on coral mineralization, Rev. Mineral. Geochem., 54, 151-187.

Cohen, A. L., G. D. Layne, S. R. Hart, and P. S. Lobel (2001), Kinetic control of skeletal $\mathrm{Sr} / \mathrm{Ca}$ in a symbiotic coral: Implications for the paleotemperature proxy, Paleoceanography, 16(1), 20-26.

Dodd, J. R. (1965), Environmental control of strontium and magnesium in Mytilus, Geochim. Cosmochim. Acta, 29, 385-398.

Elliot, M., P. B. deMenocal, B. K. Linsley, and S. S. Howe (2003), Environmental controls on the stable isotopic composition of Mercenaria mercenaria: Potential application to paleoenvironmental studies, Geochem. Geophys. Geosyst., 4(7), 1056, doi:10.1029/2002GC000425.

Epstein, S., R. Buchsbaum, H. Lowenstam, and H. Urey (1953), Revised carbonate-water isotopic temperature scale, Geol. Soc. Am. Bull., 64, 1315-1326.

Ferrier-Pages, C., F. Boisson, and D. Allemand (2002), Kinetics of strontium uptake in the scleractinian coral Stylophora pistillata, Mar. Ecol. Prog. Ser., 245, 93-100.

Gentry, K. (2005), Seasonal isotope and trace-metal profiles of serially sampled Conus gastropods: Proxies for paleoenvironmental change, M.S. thesis, 63 pp, Tex. A\&M Univ., College Station.

Gillikin, D. P., A. Lorrain, J. Navez, J. W. Taylor, L. André, E. Keppens, W. Baeyens, and F. Dehairs (2005), Strong biological controls on $\mathrm{Sr} / \mathrm{Ca}$ ratios in aragonitic marine bi- valve shells, Geochem. Geophys. Geosyst., 6, Q05009, doi:10.1029/2004GC000874.

Goodwin, D. H., B. R. Schöne, and D. L. Dettman (2003), Resolution and fidelity of oxygen isotopes as paleotemperature proxies in bivalve mollusk shells: Models and observations, Palaios, 18, 110-125.

Grossman, E. L., and T. Ku (1986), Oxygen and carbon isotope fractionation in biogenic aragonite: Temperature effects, Chem. Geol., 59, 59-74.

Ivany, L., B. Wilkinson, K. Lohmann, E. Johnson, B. McElroy, and G. Cohen (2004), Intra-annual isotopic variation in Venericardia bivalves: Implications for early Eocene temperature, seasonality, and salinity on the U.S. Gulf Coast, J. Sediment. Res., 74, 7-19.

Jones, D. S., and I. R. Quitmeyer (1996), Marking time with bivalve shells: Oxygen isotopes and season of annual increment formation, Palaios, 11, 340-346.

Kinsman, D. J. J., and H. D. Holland (1969), The co-precipitation of cations with $\mathrm{CaCO}_{3}-\mathrm{IV}$. The co-precipitation of $\mathrm{Sr}^{2+}$ with aragonite between $16^{\circ}$ and $96^{\circ}$ degrees, Geochim. Cosmochim. Acta, 33, 1-18.

Klein, R., K. Lohmann, and C. W. Thayer (1996), Sr/Ca and C-13/C-12 ratios in skeletal calcite of Mytilus trossulus: Covariation with metabolic rate, salinity, and carbon isotopic composition of seawater, Geochim. Cosmochim. Acta, 60, 4207-4221.

Kobashi, T., and E. L. Grossman (2003), The oxygen isotopic record of seasonality in Conus shells and its application to understanding late middle Eocene (38 Ma) climate, Paleontol. Res., 7, 343-355.

Kobashi, T., E. L. Grossman, T. E. Yancey, and D. T. Dockery (2001), Reevaluation of conflicting Eocene tropical temperature estimates: Molluskan oxygen-isotope evidence for warm low-latitudes, Geology, 29, 983-986.

Kobashi, T., E. L. Grossman, D. T. Dockery III, and L. C. Ivany (2004), Water mass stability reconstructions from greenhouse (Eocene) to icehouse (Oligocene) for the northern Gulf Coast continental shelf (USA), Paleoceanography, 19, PA1022, doi:10.1029/2003PA000934.

Kohn, A. J., and F. E. Perron (1994), Life History and Biogeography: Patterns in Conus, 106 pp., Oxford Univ. Press, New York.

Kohn, A. J., E. R. Myers, and V. R. Meenakshi (1979), Interior remodeling of the shell by a gastropod mollusc, Proc. Natl. Acad. Sci. U. S. A., 76, 3406-3410.

LATEX (1997), Texas-Louisiana Shelf Circulation and Transport Processes Study, NODC Proj. Code 0212, Tex. A\&M Univ., College Station, Tex.

Laws, E. (1997), Mathematical Methods for Oceanographers, 343 pp., John Wiley, Hoboken, N. J.

Lea, D., D. Pak, and H. Spero (2000), Climate impact of late Quaternary equatorial Pacific sea surface temperature variations, Science, 289, 1719-1724.

Lear, C. H., H. Elderfield, and P. A. Wilson (2000), Cenozoic deep-sea temperatures and global ice volumes from $\mathrm{Mg} / \mathrm{Ca}$ in benthic foraminiferal calcite, Science, 287, 269-272.

Lorrain, A., D. P. Gillikin, Y. Paulet, L. Chauvaud, A. Lemercier, J. Navez, and L. Andre (2005), Strong kinetic effects on $\mathrm{Sr} / \mathrm{Ca}$ ratios in the calcitic bivalve Pecten maximus, Geology, 33, 965-968.

Lutz, R. A., and D. C. Rhoads (1980), Growth Patterns Within the Molluscan Shell: An Overview in Skeletal Growth of Aquatic Organisms, 203-254 pp., Springer, New York.

Nurnberg, D., J. Bijma, and C. Hemleben (1996), Assessing the reliability of magnesium in foraminiferal calcite as a 
proxy for water mass temperatures, Geochim. Cosmochim. Acta, 60, 803-814.

Paillard, D., L. Labeyrie, and P. Yiou (1996), Macintosh program performs time-series analysis, Eos Trans. $A G U, 77,379$.

Palacios, R., J. Orensanz, and D. Armstrong (1994), Seasonal and life-long variation of $\mathrm{Sr} / \mathrm{Ca}$ ratio in shells of Mya arenaria from Grays Harbor-an ancillary criterion in demographic studies, Estuarine Coastal Shelf Sci., 39, 313-327.

Purton, L., G. Shields, M. Brasier, and G. Grime (1999), Metabolism controls $\mathrm{Sr} / \mathrm{Ca}$ ratios in fossil aragonitic ontogenetic, Geology, 27, 1083-1086.

Rosenheim, B. E., P. K. Swart, S. R. Thorrold, P. Willenz, L. Berry, and C. Latkoczy (2004), High-resolution $\mathrm{Sr} / \mathrm{Ca}$ records in sclerosponges calibrated to temperature in situ, Geology, 32, 145-148.

Rosenthal, Y., and A. Katz (1989), The applicability of trace elements in freshwater shells for paleogeochemical studies, Chem. Geol., 78, 65-76.

Rosenthal, Y., and G. P. Lohmann (2002), Accurate estimation of sea surface temperatures using dissolution-corrected calibrations for $\mathrm{Mg} / \mathrm{Ca}$ paleothermometry, Paleoceanography, 17(3), 1044, doi:10.1029/2001PA000749.

Rosenthal, Y., E. Boyle, and N. Slowey (1997), Temperature control on the incorporation of magnesium, strontium, fluorine and cadmium into benthic foraminiferal shells from Little Bahama Bank: Prospects for thermocline oceanography, Geochim. Cosmochim. Acta, 61, 3633-3643.

Rosenthal, Y., P. Field, and R. M. Sherrell (1999), Precise determination of element/calcium ratios in calcareous samples using Sector Field Inductively Coupled Plasma Mass Spectrometry, Anal. Chem., 71, 3248-3253.

Rosenthal, Y., C. H. Lear, D. W. Oppo, and B. K. Linsley (2006), Temperature and carbonate ion effects on $\mathrm{Mg} / \mathrm{Ca}$ and $\mathrm{Sr} / \mathrm{Ca}$ ratios in benthic foraminifera: Aragonitic species Hoeglundina elegans, Paleoceanography, 21, PA1007, doi:10.1029/2005PA001158.

Stecher, H., D. Krantz, C. Lord, G. Luther, and K. Bock (1996), Profiles of strontium and barium in Merceneria mercernaria and Spisula solidissima shells, Geochim. Cosmochim. Acta, 60, 3445-3456.

Takesue, R., and A. Van Geen (2004), Mg/Ca, Sr/Ca, and stable isotopes in modern and holocene Protothaca staminea shells from a northern California coastal upwelling region, Geochim. Cosmochim. Acta, 68, 3845-3861.

Tripati, A., and J. Zachos (2000), Environmental controls on $\mathrm{Sr} / \mathrm{Ca}$ and $\mathrm{Mg} / \mathrm{Ca}$ ratios in aragonitic shells of turritellid gastropods, Geol. Soc. Am. Abstr. Programs, 32, A298.

Tripati, A., and J. Zachos (2002), Late Eocene tropical sea surface temperatures: A perspective from Panama, Paleoceanography, 17(3), 1032, doi:10.1029/2000PA000605.

Wada, K., and T. Fujinuki (1976), Biomineralization in bivalve mollusks with emphasis on the chemical composition of the extrapallial fluid, in The Mechanisms of Mineralization in Invertebrates and Plants, edited by N. Watabe and K. M. Wilbur, pp. 175-190, Univ. of S. Carolina Press, Columbia.

Weber, J. N. (1973), Incorporation of strontium into reef coral skeletal carbonate, Geochim. Cosmochim. Acta, 37, $2173-$ 2190.

Wilbur, K. M., and A. S. M. Salenddin (1983), Shell formation, in The Mollusca, vol. 4, edited by K. M. Wilbur, pp. 235-287, Elsevier, New York.

Zhong, S., and A. Mucci (1989), Calcite and aragonite precipitation from seawater solutions of various salinities: Precipitation rates and overgrowth compositions, Chem. Geol., 78, 283-299. 